\title{
A Filed Study of Effect using the Internet on Iraqi Family's Relationship in Khanaqin City by Using Linear Regression
}

\author{
Maad M. Mijwil $^{1 *}$ and Sarmad M. Khazaal ${ }^{2}$ \\ ${ }^{1}$ Baghdad College of Economics Sciences University, Computer Engineering Techniques Department \\ Baghdad, Iraq \\ ${ }^{2}$ Baghdad College of Economics Sciences University, Computer Sciences Department \\ Baghdad, Iraq \\ *Corresponding author's email: mr.maad.alnaimiy [AT] baghdadcollege.edu.iq
}

\begin{abstract}
The internet and especially social media are one of the most important means of modern communication among humanity. Undoubtedly, it has played an important role in influencing the cultures of many peoples. It has had positive and negative effects. The effect of this modern technology has extended to the family. The Sociology defines a family is a group consisting of a man and a woman with whom there is a marital relationship. As a result, many problems have arisen, including all segments of society, including the important part of society and its main constituent, countryside families. In this paper, the main hypothesis was established to show whether there is a statistically significant effect on the Iraqi family's relationship in Diyala governorate and specifically in Khanaqin city, by using the linear regression equation in SPSS, which shows the effect of the Internet as well as social media sites on them.
\end{abstract}

Keywords—Linear regression, Internet, Questionnaires, Statistical.

\section{INTRODUCTION}

The Internet is the union of all the networks and computers distributed throughout the world, so it could be defined as a global network in which all the networks that use TCP / IP protocols are combined and that are compatible with each other [1]. This was created in the 60s as a military government project, however, over the years, it has evolved to such an extent that it has become indispensable for people [2].

On October 24, 1995, the Federal Networking Council of the United States unanimously approved a resolution defining the term Internet [3]. This definition was created in consultation with members of the Internet and communities of intellectual property rights and says the following: «Internet refers to the global information system that is logically connected by a single global address based on Internet Protocol (IP) or subsequent extensions; it is capable of supporting communications using the Transmission Control Protocol / Internet Protocol (TCP / IP) or subsequent extensions and/or other IP compatible protocols; and provides, uses or makes accessible, both publicly and privately, higher-level services produced in the infrastructure described. "[4]. It is seen that the Internet, which has positive and sometimes negative effects on societies, has caused some changes on human social life and culture [5]. The world is moving into an information-based communication system with the Internet, and with the help of the Internet, information is accessible to the masses by providing interactive communication opportunities, it enlarges the areas of "choice" and "freedom in of individuals and therefore, it is thought to have a positive effect on social development with the spread of information [6].

However, it is seen that disinfection, which is presented to the Internet by the sovereign institutions for the purpose of violence and consumption, can channel individuals to certain sovereign life culture and thoughts. The Internet also eliminates many features that may be important in the real world, such as distance between people, age, gender, race, culture. Thanks to the anonymous character of the Internet, people who think in the same way can easily come together, regardless of time and space, create virtual communities, and people from different cultures get to know each other, Shopping, commerce, even working from home without going to work, e-government, such as the use of social life and relationships affect people [7]. It is clear that the use of the internet changes economic life and production relations, and consequently social life. With the innovations that the Internet, which is one of the sine qua non of the information age, will lead to entertainment, clothing, human rights, national values, the concept of working culture, leisure time, letter nostalgia, e-mail communication, scientific studies and newspapers are experiencing cultural change in all areas [8]. 


\section{STATISTICS DATA ANALYSIS}

The research aims to present the results of practical application by distributing 100 questionnaires to some Iraqi families in Khanaqin and was analyzed with the aim of drawing out the general framework of the respondents preferences and attitudes by using descriptive statistical tools such as mean and standard deviation of the answers given to the questionnaire. In terms of search variables, according to the triple scale of options (agreed, neutral, I don't agree) as shown in table-1 in order to reach the results that can prove that the Internet has an effect on Iraqi family's relationship. After applied the questionnaires in SPSS, found both arithmetic mean (AM) and Standard deviation (SD) by the following equations:

I- Arithmetic mean divided two equations of $\mathrm{n}$ observation; is their sum divided by the number of observation $\mathrm{n}$

Sample mean: $\bar{x}=\sum x_{i} / n$.

Population mean: $\mu=\sum x_{i} / n$.

II- Standard deviation $=\sqrt{2}$

Table 1: shows the descriptive statistics of the questionnaire questions with mean and stander deviation

\begin{tabular}{|c|c|c|c|c|c|}
\hline Questions & $\begin{array}{l}\text { Agreed } \\
\text { Ratio }\end{array}$ & $\begin{array}{r}\text { Neutral } \\
\text { Ratio }\end{array}$ & $\begin{array}{l}\text { I don't agree } \\
\text { Ratio }\end{array}$ & Mean & $\begin{array}{l}\text { Standard } \\
\text { Deviation }\end{array}$ \\
\hline $\begin{array}{l}\text { Do you think the Internet has a positive effect } \\
\text { on people? }\end{array}$ & $69 \%$ & $12 \%$ & $19 \%$ & 2.50 & 0.798 \\
\hline $\begin{array}{l}\text { Do you think the internet has a negative effect } \\
\text { on people? }\end{array}$ & $38 \%$ & $40 \%$ & $22 \%$ & 2.16 & 0.762 \\
\hline $\begin{array}{c}\text { Do you think that using the Internet } \\
\text { continuously affects young people scientifically } \\
\text { on people? }\end{array}$ & $55 \%$ & $19 \%$ & $26 \%$ & 2.19 & 0.856 \\
\hline $\begin{array}{l}\text { Do you think that young people's use of the } \\
\text { Internet greatly affects their communication } \\
\text { with others? }\end{array}$ & $56 \%$ & $\% 27$ & $17 \%$ & 2.39 & 0.764 \\
\hline $\begin{array}{l}\text { Does addiction to Internet use lead to a state of } \\
\text { isolation among young people? }\end{array}$ & $54 \%$ & $25 \%$ & $21 \%$ & 2.33 & 0.805 \\
\hline $\begin{array}{l}\text { Does excessive use of the Internet have an } \\
\text { impact on family cohesion of the father, mother } \\
\text { and children? }\end{array}$ & $54 \%$ & $25 \%$ & $21 \%$ & 2.33 & 0.805 \\
\hline $\begin{array}{c}\text { Does Internet addiction lead to leaving religious } \\
\text { duties such as prayer, fasting, helping others } \\
\text { and other duties? }\end{array}$ & $51 \%$ & $21 \%$ & $28 \%$ & 2.23 & 0.863 \\
\hline $\begin{array}{c}\text { Does the Internet destroy many personal traits } \\
\text { and ethics among young people and help to } \\
\text { porn? }\end{array}$ & $51 \%$ & $21 \%$ & $28 \%$ & 2.23 & 0.863 \\
\hline $\begin{array}{c}\text { Does the use of the Internet reduce the creativity } \\
\text { and strength of the connection between the } \\
\text { person and his belonging to his country or } \\
\text { family or work? }\end{array}$ & $43 \%$ & $35 \%$ & $22 \%$ & 2.21 & 0.782 \\
\hline $\begin{array}{l}\text { Does the Internet increase frustration and get } \\
\text { away from reality? }\end{array}$ & $37 \%$ & $35 \%$ & $28 \%$ & 2.09 & 0.805 \\
\hline $\begin{array}{l}\text { Do you think the use of the Internet is a } \\
\text { standard or of personal components? }\end{array}$ & $36 \%$ & $40 \%$ & $24 \%$ & 2.12 & 0.769 \\
\hline
\end{tabular}




\begin{tabular}{|c|c|c|c|c|c|}
\hline $\begin{array}{c}\text { Do you think the Internet have advantages more } \\
\text { than its disadvantages? }\end{array}$ & $41 \%$ & $30 \%$ & $29 \%$ & 2.12 & 0.832 \\
\hline $\begin{array}{l}\text { Do you think the use of the Internet increasingly } \\
\text { leads to isolation from the world? }\end{array}$ & $45 \%$ & $35 \%$ & $20 \%$ & 2.25 & 0.770 \\
\hline $\begin{array}{l}\text { Do you think that online browsing affects your } \\
\text { overall knowledge? }\end{array}$ & $38 \%$ & $35 \%$ & $27 \%$ & 2.11 & 0.803 \\
\hline $\begin{array}{l}\text { Does the use of the internet lead to loss and } \\
\text { inability to exploit time appropriately? }\end{array}$ & $50 \%$ & $20 \%$ & $30 \%$ & 2.20 & 0.876 \\
\hline $\begin{array}{l}\text { Does the Internet effect on the human body } \\
\text { organs such as the eyes or the neck? }\end{array}$ & $66 \%$ & $22 \%$ & $12 \%$ & 2.54 & 0.702 \\
\hline $\begin{array}{c}\text { Does the Internet help people get to know the } \\
\text { world quickly and effectively? }\end{array}$ & $64 \%$ & $24 \%$ & $12 \%$ & 2.52 & 0.703 \\
\hline $\begin{array}{l}\text { Does the Internet help people gain useful and } \\
\text { new information? }\end{array}$ & $65 \%$ & $18 \%$ & $17 \%$ & 2.48 & 0.770 \\
\hline $\begin{array}{l}\text { Do you feel comfortable when using the } \\
\text { Internet? }\end{array}$ & $47 \%$ & $17 \%$ & $36 \%$ & 2.11 & 0.909 \\
\hline $\begin{array}{l}\text { Are you bored because you don't use the } \\
\text { Internet in your daily life? }\end{array}$ & $37 \%$ & $21 \%$ & $42 \%$ & 1.95 & 0.892 \\
\hline $\begin{array}{l}\text { Do people resort to using the Internet too much } \\
\text { to express themselves directly or indirectly? }\end{array}$ & $\% 56$ & $\% 25$ & $\% 19$ & 2.37 & 0.787 \\
\hline $\begin{array}{c}\text { Do you think that the denial of friends makes } \\
\text { many human use the Internet to fill the } \\
\text { shortfall? }\end{array}$ & $\% 41$ & $\% 31$ & $\% 28$ & 2.13 & 0.825 \\
\hline $\begin{array}{l}\text { Do you think that young people become } \\
\text { imitators in a way that does not suit the customs } \\
\text { and traditions of the society when they use the } \\
\text { Internet and wipe their personality as well? }\end{array}$ & $43 \%$ & $\% 29$ & $\% 28$ & 2.15 & 0.833 \\
\hline $\begin{array}{l}\text { Do people rely on knowledge of things, for } \\
\text { example, fashion or development in the world } \\
\text { on the Internet? }\end{array}$ & $55 \%$ & $\% 33$ & $\% 12$ & 2.43 & 0.700 \\
\hline $\begin{array}{c}\text { Do you think that some young people are trying } \\
\text { to acquire foreign languages via internet chat } \\
\text { programs? }\end{array}$ & $48 \%$ & $\% 34$ & $\% 18$ & 2.30 & 0.759 \\
\hline $\begin{array}{l}\text { Do you think that weakness association and } \\
\text { meeting with others is caused by the misuse of } \\
\text { the Internet? }\end{array}$ & $54 \%$ & $26 \%$ & $20 \%$ & 2.34 & .0 .794 \\
\hline $\begin{array}{l}\text { Do people choose to use the Internet and enjoy } \\
\text { it to chat and sit with others? }\end{array}$ & $35 \%$ & $38 \%$ & $27 \%$ & 2.08 & 0.787 \\
\hline $\begin{array}{l}\text { Do you feel strange when you sit with people } \\
\text { who are addicted to using the Internet? }\end{array}$ & $50 \%$ & $26 \%$ & $24 \%$ & 2.26 & 0.824 \\
\hline $\begin{array}{l}\text { Do you feel negative feelings such as loneliness } \\
\text { and sitting with others while using the Internet? }\end{array}$ & $45 \%$ & $30 \%$ & $25 \%$ & 2.20 & 0.816 \\
\hline $\begin{array}{l}\text { Do ethics violate in to achieve your wishes } \\
\text { when you use the Internet? }\end{array}$ & $33 \%$ & $41 \%$ & $26 \%$ & 2.07 & 0.769 \\
\hline
\end{tabular}




\begin{tabular}{|c|c|c|c|c|c|}
\hline $\begin{array}{c}\text { Do you feel the people around you when you } \\
\text { are busy using the Internet somewhere? }\end{array}$ & $47 \%$ & $28 \%$ & $25 \%$ & 2.22 & 0.824 \\
\hline $\begin{array}{c}\text { Does the Internet affect people who use it daily } \\
\text { and continuously, on their behaviour and } \\
\text { appearance? }\end{array}$ & $40 \%$ & $34 \%$ & $26 \%$ & 2.14 & 0.804 \\
\hline $\begin{array}{c}\text { Do you feel that the chat programs have not } \\
\text { evolved from your general culture? }\end{array}$ & $30 \%$ & $43 \%$ & $27 \%$ & 2.03 & 0.758 \\
\hline $\begin{array}{c}\text { Do you think that applications on the internet } \\
\text { affect your mental state and help you to forget } \\
\text { your problems? }\end{array}$ & $34 \%$ & $35 \%$ & $31 \%$ & 2.03 & 0.810 \\
\hline $\begin{array}{c}\text { Do you think that the number of friends in the } \\
\text { community will be less when Internet usage } \\
\text { increases? }\end{array}$ & $38 \%$ & $39 \%$ & $23 \%$ & 2.15 & 0.770 \\
\hline $\begin{array}{c}\text { Does the internet affect your relationships like } \\
\text { love, work relationships or any other type of } \\
\text { relationship because of the frequent use it? }\end{array}$ & $35 \%$ & $43 \%$ & $22 \%$ & 2.13 & 0.747 \\
\hline $\begin{array}{c}\text { Can you leave and not use the internet for long } \\
\text { time? }\end{array}$ & $32 \%$ & $36 \%$ & $32 \%$ & 2.00 & 0.804 \\
\hline $\begin{array}{c}\text { Do you feel unable to do business because of } \\
\text { the frequent use of the Internet? }\end{array}$ & $30 \%$ & $40 \%$ & $30 \%$ & 2.00 & 0.778 \\
\hline $\begin{array}{c}\text { Does the brain become unable to concentrate } \\
\text { during the day-to-day activities and cognitive } \\
\text { functions decline due to the use of the Internet? }\end{array}$ & $46 \%$ & $28 \%$ & $26 \%$ & 2.20 & 0.829 \\
\hline $\begin{array}{c}\text { Does the Internet contribute to making a person } \\
\text { quiet and not a social and have a few friends? }\end{array}$ & $49 \%$ & $24 \%$ & $27 \%$ & 2.22 & 0.848 \\
\hline
\end{tabular}

\section{MAIN HYPOTHESES}

Linear regression analysis is a statistical technique used to study the relationship between quantitative variables [9]. Both in the case of two variables (simple regression) and in more than two variables (multiple regression), the linear regression analysis can be used to explore and quantify the relationship between a variable called a dependent or criterion (Y) one or more variables called independent or predictive $(\mathrm{X} 1, \mathrm{X} 2, \ldots, \mathrm{Xn})$, as well as to develop a linear equation for predictive purposes [10]. Now it is assumed that $Y$ can be written as $f(X)$ for a function $f$ - estimating this function $y=f$ (x) from observation data is called regression. A simple linear regression follows the following model:

$\mathrm{Y}=\mathrm{a}+\mathrm{b} * \mathrm{X}$

where $\mathrm{a}$ and $\mathrm{b}$ represent the regression coefficients, concretely a stands for the constant and $\mathrm{b}$ for the slope of the regression line.

Through table- 2 where the correlation coefficients are $R=0.40$, while the Selection coefficient is $\mathrm{R}^{2}=0.16$, the corrected coefficient of $\mathrm{R}^{2-}=0.15$, which means that the independent variable (used of the internet) (explanatory) was able to explain the changes in the dependent variable (0.15) and the rest due to other factors.

The value of $B=0.447$ in the sense that the change in the variable used of the Internet leads to change in the variable of family relationship in Iraq, the value of (0.447), and confirmed T-test significance of this change (Effect) of (4.255) The significance of this change is (18.104), which is greater than the tabular value of (4.002) and the level of statistical significance (0.000) Also note that the level of significance accepted in this study is up to (0.05). This means acceptance of the alternative hypothesis (there is a significant statistical of the variable for use of the Internet on Iraqi family's relationship) identified by the study and reject the null hypothesis. 
Table 2: shown the Simple Linear Regression Analysis of an effect of the Internet on Iraqi family's relationship

\begin{tabular}{|c|c|c|c|c|c|c|c|c|}
\hline variable & B & $\begin{array}{l}\mathrm{T}- \\
\text { test }\end{array}$ & $\begin{array}{c}\text { P-value } \\
\text { (Sig) }\end{array}$ & F-calculated & $\begin{array}{c}\text { F- } \\
\text { Table }\end{array}$ & $\mathrm{DF}(\mathrm{T})$ & $\begin{array}{l}\text { T-table } \\
\alpha=0.05\end{array}$ & $\begin{array}{c}\text { Statistical } \\
\text { Hypothesis } \\
\text { Testing }\end{array}$ \\
\hline $\begin{array}{l}\text { Use the } \\
\text { Internet }\end{array}$ & 0.447 & 4.255 & 0.000 & 18.104 & 4.002 & 99 & 1.990 & $\begin{array}{c}\text { Alternate } \\
\text { Hypothesis }\end{array}$ \\
\hline \multicolumn{7}{|c|}{$\mathrm{R}=0.40$} & $R^{2}=0.16$ & $R^{2-}=0.15$ \\
\hline
\end{tabular}

\section{CONCLUSIONS}

Everyone knows the internet nowadays. Without the Internet, the PC, the smartphone or the tablet will appear much more lifeless and useless. No chats with friends, no surfing of favorite websites, no online shopping, no news feeds, or what happens with friends and acquaintances at the moment. There are many programs that are useful and contribute to the provision of knowledge as well as there are programs and sites that have negative results for the community, so many of the companies of the development of the technology of the Internet to enhance the awareness of people in terms of information and enrich User applications in dealing with digital services e.g. Internet services provided by Google, which contains millions of information that serve and support the community.

\section{REFERENCES}

[1] Kahn R. E. and Cerf V. G., What Is the Internet and what makes it work, December 1999.

[2] Schafer V. and Serres A., Histories of the internet and the web, living books about history, April 2017.

[3] Almagor R. C., Internet History. International Journal of Techno ethics, 2(2): 45-64, June 2011.

[4] McGarty T. P., The Internet Protocol (IP) and Global Telecommunications Transformation, July 2002.

[5] Corcoran M., The impact of new media technologies on social interaction in the household, SO303H Electronic Culture and Social Change, April 2012.

[6] Chukwuere J. E. and Chukwuere P. C., The impact of social media on social lifestyle: a case study of university female students, Ife center for psychological studies/services, Ile-Ife, Nigeria, December 2017.

[7] J. Anderson, L. Rainie and A. Luchsinger, Artificial Intelligence and the Future of Humans, PEW research center and elon university's imagining the internet center, December 2018.

[8] Kumar T.M.V and Dahiya B., Smart Economy in Smart Cities, Education $1^{\text {st, }}$ Chapter 1, Springer, January 2017.

[9] Bewick V., Cheek L. and Ball J., Statistics review 7: Correlation and regression, November 2003 http://ccforum.com/content/7/6/451

[10] Uyanık G. K. and Güler N., A Study on Multiple Linear Regression Analysis, Procedia - Social and Behavioral Sciences, December 2013. 